\title{
Relationship between early development of plant community and environmental condition in abandoned paddy terraces at mountainous valleys in Korea
}

\author{
Jihyun Park, Mun-Gi Hong, Jae Geun Kim** \\ Department of Biology Education, Seoul National University, Seoul 151-748, Korea
}

\begin{abstract}
In Korea, many paddy fields in mountainous area have been abandoned because of their low accessibility and rice price and the abandoned paddy terraces have changed into natural lentic wetlands. To understand the relationship between characteristics of environmental conditions and early development of plant community in abandoned paddy terraces, we investigated at four well-maintained abandoned paddy terraces in 3 different climatic zones in Korea. Soil texture of abandoned paddy terraces was mostly kinds of loam and electric conductivity of soil was also similar among abandoned paddy terraces. On the other hand, contents of nitrogen, phosphorus, potassium, sodium, magnesium, and calcium in soil were relatively low and significantly different among abandoned paddy terraces. Water depth was different within sites and inter-sites. Although environmental conditions including climate, soil condition and water depth were different among abandoned paddy terraces, the compositions of plant communities were relatively similar in all abandoned paddy terraces. 55 dominant taxa out of 141 recorded species were commonly recorded over sites and they were mostly perennial obligate wetland plants and facultative wetland plants. 8 taxa out of 55 dominant taxa occurred at all abandoned paddy terraces with over $10 \%$ coverage. Several site-specific species occurred at site, which have some area with deep water level. This result indicates that early development of plant community in abandoned paddy terraces of similar water regime is similar in the entire area of Korea even though environmental conditions such as climate, biogeographic history and soil are different.
\end{abstract}

Keywords: hydrophytes, Korean wetlands, succession, water depth, wetland plants

\section{INTRODUCTION}

At the regional scale, differences in climate, physical geomorphology, biogeographic history, and large-scale patterns of human land use can lead to differences in available species pools (Rickelfs 1987, Zobel 1992, Foster et al. 2003). Within the region, surrounding land uses, site isolation, and site area influence plant species composition by determining rates of propagule input (Matthews et al. 2009). Wetlands are also affected of hydrology, physico-chemical environment (Mitsch and Gosselink 2007). Hydrology regime is considered to be importance in determining characteristics of wetland plant communities (Keddy 2000, Mitsch and Gosselink 2007). Depth, duration, and frequency of flooding are major controls of seed germination and establishment (van der Valk 1981, Casanova and Brock 2000), boundaries between woody and herbaceous vegetation (Toner and Keddy

\section{Open Access http://dx.doi.org/10.5141/ecoenv.2013.017}

This is an Open Access article distributed under the terms of the Creative Commons Attribution Non-Commercial License (http://creativecommons. org/licenses/by-nc/3.0/) which permits unrestricted non-commercial use, distribution, and reproduction in any medium, provided the original work is properly cited.
Received 5 January 2013, Accepted 10 June 2013

*Corresponding Author

E-mail: jaegkim@snu.ac.kr

Tel: +82-2-880-7896 
1997), plant productivity and diversity (Fennessy et al. 1994), and species composition (Weiher and Keddy 1995). It also determines the frequency and intensity of flood disturbance, which creates topographic differences and erosion (Naiman and Decamps 1997). Apart from those, other important factors of the plant composition in wetlands include fertility, salinity, competitiveness between plants and herbivores (Keddy 2000). Soil fertility is also a determinant of plant community and diversity in wetlands (Weiher and Keddy 1995) because wetland soils are both the medium in which many of the wetland chemical transformations take place and the primary storage of available chemicals for most wetland plants (Mitsch and Gosselink 2007), so that nutrient enrichment could increase growth of invasive species (Green and Galatowitsch 2002, Kercher and Zedler 2004, Rickey and Anderson 2004, Rejmankova 2011) and these environmental conditions could lead a different stage of succession.

As paddy cropping was especially important economic activity in Asia, many paddy fields and paddy terraces in mountainous valleys were developed for intensive agricultural systems (Kim et al. 2006, Park et al. 2006). Since the improvement of socio-economic conditions, there was low economic benefit due to decrease in consumption of rice, rural exodus of farmers, and government agricultural policies aiming to reduce overpopulation, paddy fields have been increasingly abandoned (Park et al. 2006, Byun et al. 2008). Especially, because of being located at mountainous valley, paddy terraces were inaccessible and unfavorable farming conditions such as inclining topography, small terraced plots, and levee grasses that were hard to mow, they have been getting non-cropped land and they did not be cared (Fukamachi et al. 2005). Although they were the largest man-made wetland ecosystems at first, they have changed into natural wetlands after abandonment (Lee et al. 2002, Kim et al. 2006, Yamada et al. 2007). Therefore, they could provide a function of foods and protection of fowl, and habitats which could increase biodiversity (Comin et al. 2001).

Until now, abandoned paddy fields have been studied for plant succession within near-regional but these abandoned paddy terraces were distributed to several locations with mountain ranges in Korea. After abandonment, they were transformed from artificial wetlands into natural wetland by being affected by environmental condition. Diverse plant species could be established according to hydrology regime and soil condition and they could be in the different development stage of plant community. Here, we investigated physico-chemical characteristics and plant community of abandoned paddy ter-
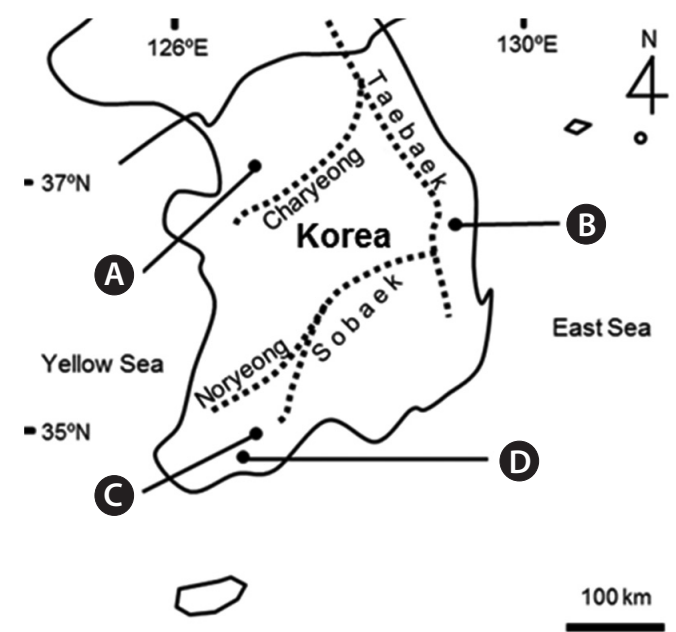

Fig. 1. Locations of four study sites. A, Ansan in Gyeonggi-do; B, Uljin in Gyeongsangbuk-do; C, Gokseong in Jeollanam-do; D, Boseong in Jeollanam-do in South Korea (Solid line across the map indicated the $38^{\text {th }}$ parallel and broken lines indicated mountain ranges on the map.).

races which represent three regions disconnected by the mountain ranges, which divide watersheds and climate zones. The object of this study is to reveal the relationship between characteristics of environmental conditions and early development of plant community at abandoned paddy terraces in South Korea.

\section{MATERIALS AND METHODS}

\section{Study sites}

Study sites were located at mountainous valley in Ansan (site A, $37^{\circ} 17^{\prime} 10.68^{\prime \prime} \mathrm{N}, 137^{\circ} 55^{\prime} 25.96^{\prime \prime} \mathrm{E}, 107 \mathrm{~m}$ a.s.l., $6,353 \mathrm{~m}^{2}$ ) in Gyeonggi-do, Uljin (site B, $36^{\circ} 54^{\prime} 26.43^{\prime \prime} \mathrm{N}$, $129^{\circ} 24^{\prime} 46.47^{\prime \prime} \mathrm{E}, 35 \mathrm{~m}$ a.s.l., $2,345 \mathrm{~m}^{2}$ ) which was located $0.33 \mathrm{~km}$ off the coast in Gyeongsangbuk-do, Gokseong (site C, $35^{\circ} 15^{\prime} 53.38 \mathrm{~N}, 127^{\circ} 16^{\prime} 09.68^{\prime \prime} \mathrm{E}, 115 \mathrm{~m}$ a.s.l., 5,102 $\mathrm{m}^{2}$ ), and Boseong (site $\mathrm{D}, 34^{\circ} 48^{\prime} 21.53^{\prime \prime} \mathrm{N}, 127^{\circ} 04^{\prime} 55.96^{\prime \prime} \mathrm{E}$, $158 \mathrm{~m}$ a.s.l., 14,020 m²) in Jeollanam-do in Korea (Fig. 1). They represent three regions distributed by the mountain ranges which determine watersheds and climate zones. We selected study sites which were approximately abandoned since between 10 and 15 years, composed of over five floors, and well-maintained in terms of levee structure or water regime after being uncared. Ground matrix of four study sites was granite gneiss (Korea Institute of Geoscience and Mineral Resources 2012). The main water source was surface water. Even though monsoonal climate experiences heavy rain during summer season, the 

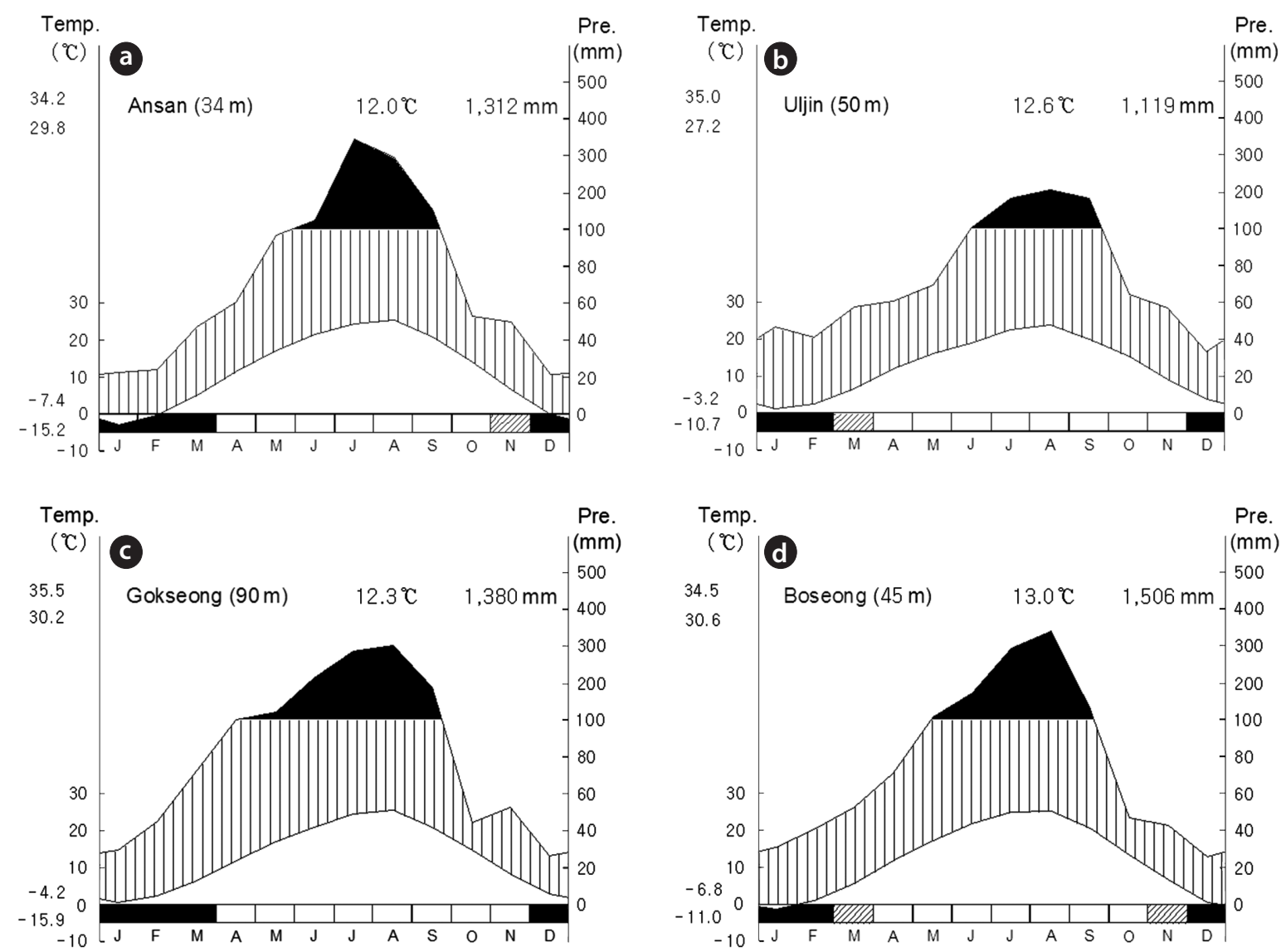

Fig. 2. Climate diagrams of four study sites, Ansan (a), Uljin (b), Gokseong (c), and Boseong (d), during 1981 - 2010. Temp., temperature; Pre., precipitation.

water depth in these sites was kept at a constant level by slopes and dikes with excess water flowing out downhill. Mean temperature and precipitation for 30 years were quietly different among the study sites overall (Fig. 2). Especially, mean precipitation of site B was lower than the other sites. Site C and D located in south showed more amount of mean precipitation and higher mean temperature than the other sites.

\section{Soil condition and water depth}

Soil samples were randomly collected at five points in each floor with a depth of $0 \sim 5 \mathrm{~cm}$ from the surface by using a soil hand auger. Gravel and large organic debris were removed from samples by being passed through 2 $\mathrm{mm}$ sieve (standard sieve \#10). Soil texture was determined using the hydrometer analysis method and the texture triangle of USDA (Carter 1993). Water content was determined after drying the samples at $105^{\circ} \mathrm{C}$ in an oven for overnight (Topp 1993). Organic matter content was analyzed by the loss-on ignition method (LOI) (Boyle 2004). Soil solutions were prepared by mixing the soil samples with distilled water at a mass ratio of 1 to 5 and $\mathrm{pH}$ and conductivity (CON) were measured, using a $\mathrm{pH}$ meter (AP63; Fisher, Hampton, USA) and a conductivity meter (Model 311; Corning, Lowell, USA), respectively. $\mathrm{NO}_{3}-\mathrm{N}$ and $\mathrm{NH}_{4}-\mathrm{N}$ were extracted with $2 \mathrm{M} \mathrm{KCl}$ solutions (Kim et al. 2004) and measured colorimetrically using the hydrazine and indophenol methods, respectively (Murphy and Riley 1962, Kamphake et al. 1967). $\mathrm{PO}_{4}-\mathrm{P}$ was extracted with Bray No. 1 solution (Bray and Kurtz 1945) and measured colorimetrically using the ascorbic acid reduction method (Solorzano 1969). Available $\mathrm{K}^{+}, \mathrm{Ca}^{2+}, \mathrm{Na}^{+}$, and $\mathrm{Mg}^{2+}$ were extracted with $1 \mathrm{~N}$ ammonium acetate solution (Allen et al. 1974) and measured with an atomic absorption spectrometer (Model AA240FS, Varian, Palo Alto, CA, USA).

Water depth was repeatedly measured at five points at each floor. Water depth was measured during the early growing season before the rainy season in 2011. 


\section{Flora and vegetation composition}

The flora list and vegetation map about dominant species were recorded at each floor during summer season in 2011. Each floor in the same area was to be a quadrat and there was repetition at the study site. The flora was investigated by passing all over the floors. Figuring out the dominant species in the map of the vegetation composition was determined by showing over $10 \%$ at each floor. The taxonomic nomenclature designated by Lee (2003) was used to identify each plant species. Species richness was obtained by counting the number of species in the whole sites. The Shannon-Weaver diversity index $\left(H^{\prime}\right)$ was used for the vegetation data in study sites (Shannon and Weaver 1949).

$$
H^{\prime}=-\sum_{i=1}^{\mathrm{s}} P_{i} \ln P_{i}
$$

where $P_{i}=$ coverage of species $i /$ total coverage

\section{Data analysis}

To examine and identify the similarities and/or differences in physico-chemical characteristics and plant community, correspondence analysis (CA) was conducted using the vegan-package 2.0-5 (Okasanen et al. 2012) in $R$ program version 2.15.1. The CA ordinations based on the environment factor-site matrix table and the species-site matrix table were carried out. The specific cover data was placed into the species relative coverage.

Duncan's post-hoc tests were conducted to identify specific differences at the $5 \%$ significance level using SPSS version 20.0 for Windows (SPSS, Inc., Chicago, IL, USA).

\section{RESULTS}

\section{Soil condition and water depth}

There were significant differences among abandoned paddy terraces in soil characteristics (Table 1). Soil texture was silt loam or sandy loam in most floors. Water contents and organic matter contents within and among abandoned paddy terraces were similar, but site $\mathrm{C}$ was slightly higher than the others. The conductivity ranged from 30 to $40 \mu \mathrm{S} / \mathrm{cm}$ in all abandoned paddy terraces and did not show significant difference among abandoned paddy terraces but $\mathrm{pH}$ ranged from 4 to 6 and showed a little difference among the abandoned paddy terraces. $\mathrm{NO}_{3}-\mathrm{N}$ was similar in all abandoned paddy terraces but $\mathrm{NH}_{4}-\mathrm{N}$ and $\mathrm{PO}_{4}-\mathrm{P}$ were quite different among abandoned paddy terraces. $\mathrm{NH}_{4}-\mathrm{N}$ was the least in site $\mathrm{B}$. $\mathrm{PO}_{4}-\mathrm{P}$ was about eight times higher in site $\mathrm{B}$ and $\mathrm{D}$ than the others. The contents of major cations were mostly higher in site B which was located near the seashore than the others. Especially, $\mathrm{Mg}^{2+}$

Table 1. Soil conditions and water depth in abandoned paddy terraces (mean \pm SD)

\begin{tabular}{|c|c|c|c|c|}
\hline & Site A $(N=7)$ & Site $B(N=5)$ & Site $C(N=7)$ & Site $D(N=8)$ \\
\hline Sand (\%) & $40.7 \pm 20.1^{\mathrm{a}}$ & $44.3 \pm 2.4^{\mathrm{a}}$ & $42.3 \pm 2.1^{\mathrm{a}}$ & $39.2 \pm 4.7^{\mathrm{a}}$ \\
\hline Clay (\%) & $6.8 \pm 3.9^{\mathrm{b}}$ & $5.0 \pm 0.9^{\mathrm{ab}}$ & $3.4 \pm 1.6^{\mathrm{a}}$ & $4.7 \pm 1.1^{\mathrm{ab}}$ \\
\hline Silt (\%) & $52.5 \pm 16.3^{\mathrm{a}}$ & $50.8 \pm 2.1^{\mathrm{a}}$ & $54.3 \pm 2.8^{\mathrm{a}}$ & $56.1 \pm 4.2^{\mathrm{a}}$ \\
\hline Soil texture & $\begin{array}{l}\text { Silt loam or } \\
\text { sandy loam }\end{array}$ & $\begin{array}{l}\text { Silt loam or } \\
\text { sandy loam }\end{array}$ & Silt loam & $\begin{array}{l}\text { Silt loam or } \\
\text { sandy loam }\end{array}$ \\
\hline Organic matter content $(\%)$ & $5.0 \pm 0.8^{\mathrm{a}}$ & $5.0 \pm 0.6^{\mathrm{a}}$ & $4.1 \pm 1.5^{\mathrm{a}}$ & $7.4 \pm 1.6^{\mathrm{b}}$ \\
\hline Water content $(\%)$ & $34.8 \pm 4.8^{\mathrm{a}}$ & $33.2 \pm 1.0^{\mathrm{a}}$ & $37.7 \pm 8.9^{\mathrm{a}}$ & $46.9 \pm 8.5^{\mathrm{b}}$ \\
\hline Conductivity $(\mu \mathrm{S} / \mathrm{cm})$ & $31.8 \pm 4.5^{\mathrm{a}}$ & $43.0 \pm 8.4^{\mathrm{b}}$ & $29.3 \pm 1.3^{\mathrm{a}}$ & $32.4 \pm 3.8^{\mathrm{a}}$ \\
\hline $\mathrm{pH}$ & $4.7 \pm 1.1^{\mathrm{a}}$ & $6.3 \pm 0.2 b$ & $5.4 \pm 0.3^{\mathrm{a}}$ & $5.2 \pm 0.1^{\mathrm{a}}$ \\
\hline $\mathrm{NO}_{3}-\mathrm{N}(\mathrm{mg} / \mathrm{kg})$ & $2.9 \pm 0.3^{\mathrm{a}}$ & $2.6 \pm 0.4^{\mathrm{a}}$ & $3.5 \pm 0.8^{\mathrm{a}}$ & $3.5 \pm 1.3^{\mathrm{a}}$ \\
\hline $\mathrm{NH}_{4}-\mathrm{N}(\mathrm{mg} / \mathrm{kg})$ & $10.0 \pm 6.7^{\mathrm{ab}}$ & $5.4 \pm 1.4^{\mathrm{a}}$ & $10.4 \pm 4.7^{\mathrm{ab}}$ & $12.2 \pm 4.9^{\mathrm{b}}$ \\
\hline $\mathrm{PO}_{4}-\mathrm{P}(\mathrm{mg} / \mathrm{kg})$ & $3.4 \pm 2.9^{\mathrm{a}}$ & $24.1 \pm 16.5^{\mathrm{b}}$ & $3.1 \pm 1.2^{\mathrm{a}}$ & $21.5 \pm 13.4^{\mathrm{b}}$ \\
\hline $\mathrm{K}^{+}(\mathrm{mg} / \mathrm{kg})$ & $52.6 \pm 6.8^{\mathrm{a}}$ & $97.5 \pm 57.4^{\mathrm{b}}$ & $41.2 \pm 9.3^{\mathrm{a}}$ & $54.3 \pm 18.0^{\mathrm{a}}$ \\
\hline $\mathrm{Ca}^{2+}(\mathrm{mg} / \mathrm{kg})$ & $248.1 \pm 40.7^{\mathrm{a}}$ & $1520.1 \pm 284.4^{\mathrm{b}}$ & $397.7 \pm 124.2^{\mathrm{a}}$ & $430.7 \pm 207.2^{\mathrm{a}}$ \\
\hline $\mathrm{Na}^{+}(\mathrm{mg} / \mathrm{kg})$ & $24.6 \pm 5.7^{\mathrm{a}}$ & $59.4 \pm 8.8^{\mathrm{c}}$ & $18.0 \pm 5.1^{\mathrm{a}}$ & $35.4 \pm 9.8^{\mathrm{b}}$ \\
\hline $\mathrm{Mg}^{2+}(\mathrm{mg} / \mathrm{kg})$ & $66.7 \pm 9.9^{\mathrm{a}}$ & $323.0 \pm 74.5^{\mathrm{b}}$ & $48.0 \pm 10.8^{\mathrm{a}}$ & $75.4 \pm 38.1^{\mathrm{a}}$ \\
\hline Water depth $(\mathrm{cm})$ & $6.0 \pm 2.2^{\mathrm{a}}$ & $7.4 \pm 2.5^{\mathrm{a}}$ & $33.3 \pm 14.2^{\mathrm{b}}$ & $28.8 \pm 5.2^{\mathrm{b}}$ \\
\hline
\end{tabular}

Each letter denotes statistically different sub-groups by Duncan's test, $P<0.05$. 


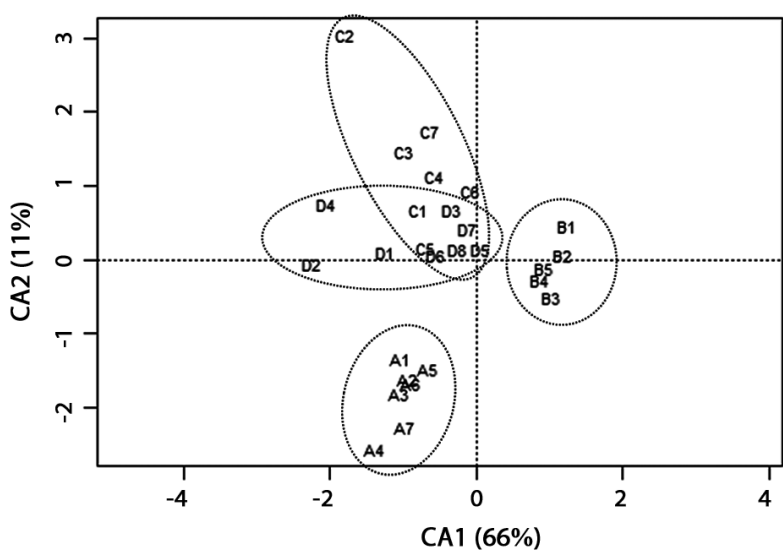

Fig. 3. Correspondence analysis of the 27 floors based on physicochemical characteristics. Labels indicate location of abandoned paddy terraces (A, Ansan; B, Uljin; C, Gokseong; D, Boseong) and floor numbers. Ellipses were drawn around each abandoned paddy terrace.

and $\mathrm{Ca}^{2+}$ contents were much higher than the others. The average water depth was higher in site $\mathrm{C}$ and $\mathrm{D}$ than the others, and site $\mathrm{C}$ particularly showed a high gradient of water level among floors.

To identify the similarities and/or differences in physico-chemical characteristics among the floors and abandoned paddy terraces, CA ordination was carried out (Fig. 3). In CA ordination, axes 1 and 2 accounted for $66.3 \%$ (eigenvalue $=0.10)$ and $11.5 \%$ (eigenvalue $=0.02)$ of total variance, respectively. Sites with relatively strong loadings on axis 1 and 2 were water depth (score $=-0.79$ and 0.69 , respectively). As a result, floors in the same site were completely grouped but the sites were divided into each location, and site $\mathrm{C}$ and $\mathrm{D}$ were overlapped in several floors.

\section{Flora and vegetation composition}

A total of 141 species were recorded in four sites. According to wetlands indicator category (US Fish and Wildlife Service 1996), there was a large amount in obligated wetland plant $(\mathrm{OBW})$ and facultative wetland plant (FACW), but obligated upland plant (OBU) was also counted highly in this study (Fig. 4). Particularly, a large amount of OBW was showed in site $\mathrm{C}$ and $\mathrm{D}$ which were higher water level than the others, and site $\mathrm{C}$ was especially showed the highest ratio of OBW. About life-forms of plants, perennial herbaceous plants largely took up and then annual herbaceous plants were occupied. Site A showed a large coverage of shrub. Site $\mathrm{C}$ comparatively showed a high ratio of annual herb because site $\mathrm{C}$ showed a gradient of the water depth. Most of the plants were hygrophyte, indicating mostly aquatic environment, wet
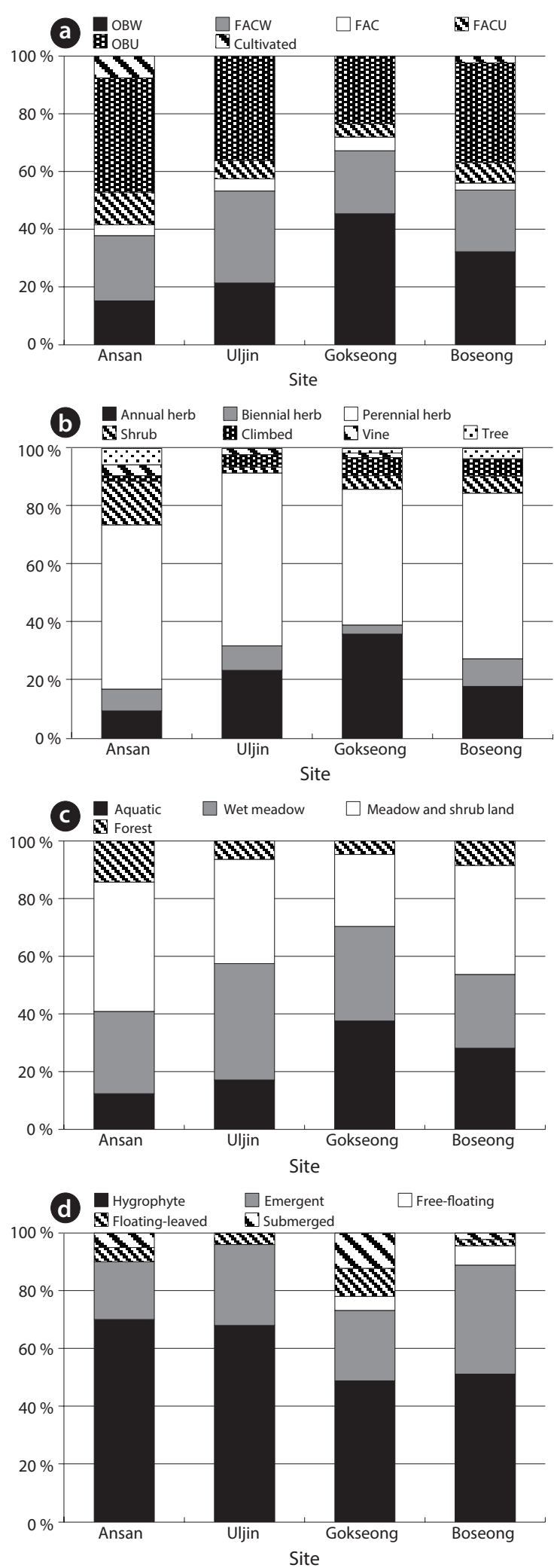

Fig. 4. Characteristics of plant communities identified in abandoned paddy terraces. (a) Wetland indicator, (b) Life-form, (c) Habitats, (d) Growth-form. OBW: Aobligate wetland plants, FAW: facultative wetland, plants FAC: facultative plants, FAU: Facultative upland plants, OBU: obligate upland plants. 


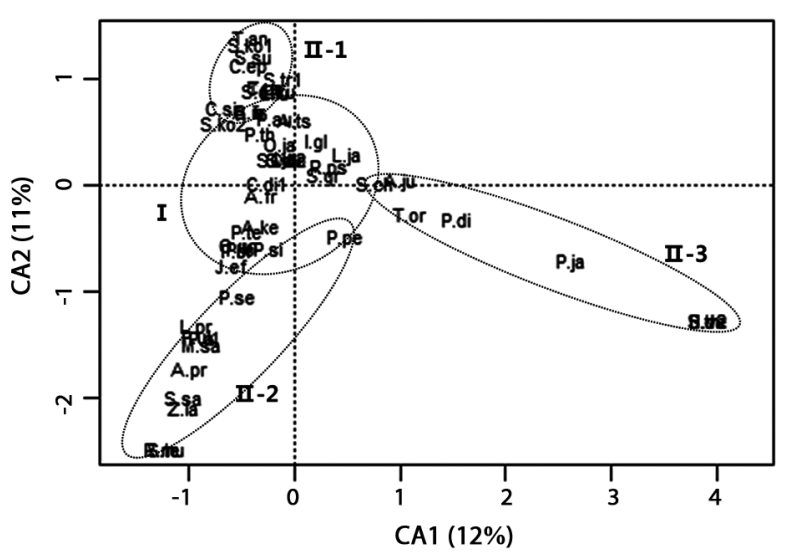

Fig. 5. Correspondence analysis of the 55 dominant plant species included relative coverage in abandoned paddy terraces. Three characters indicate abbreviation of scientific names (one character is a generic name and two characters are specific epithet. See Table 3 for abbreviation). Ellipses were drawn around a status of each group (group I, species occurred at several sites; group II, species occurred at only one site).

meadow or meadow and shrub land. In particular, submerged and floating-leaved plant communities occurred at high ratio in site C. Additionally, rare species Bletilla striata (Thunb. ex Murray) Reichb. Fil. and endangered species Penthorum chinense Pursh were found in site A and $\mathrm{D}$, respectively. We could determine that there were similar abandoned year by measuring coverage of tree layer especially Salix koreensis and S. chaenomeloides Kimura. The coverage of tree layer was not showed all over the floors. But some floors in the site Boseong showed about $10 \%$ coverage of $S$. koreensis and other floors in the site Gokseong showed about $10 \%$ coverage of S. chaenomeloides Kimura. The rest of the floors showed about from $10 \%$ to $20 \%$ of the coverage of the shrub layer, especially $S$. gracilistyla Miquel and Amorpha fruticosa $\mathrm{L}$.

Mean of species richness per floor and diversity index were $22.67 \pm 6.25$ and $1.56 \pm 0.25$, respectively (Table 2 ). Species richness was the largest in site D and the least in site A. However, species richness per square meter was not different between Site A and D and the highest in site B. Shannon's diversity was the largest in site A and B, but the least $\mathrm{C}$.

Among the 141 species, a total of 93 species occurred in all sites. A total of 55 species were recorded as dominant species by sum of the whole sites (Table 3 ). In order to identify the similarities and/or differences in the plant communities among the sites, CA ordination was carried out (Fig. 5). In CA ordination, axes 1 and 2 accounted for $12.1 \%$ (eigenvalue $=0.76)$ and $11.1 \%$ (eigenvalue $=0.70)$ of total variance, respectively. Relatively strong loadings on axis 1 were S. triangulatus (score $=3.92)$, Eleocharis dulcis (3.92), Phragmites japonica (2.63), Ludwigia prostrata $(-0.91)$ which were recorded in specific sites, group II. On the other hand, relatively weak loadings on the axis 1 were Persicaria thunbergii $(-0.32), P$ australis $(-0.18)$ and Leersia japonica $(-0.08)$ which occurred at all sites, group I. Group I included major dominant plant species which were mostly FACW / OBW and perennial herbaceous plant species. Plant species in group II were divided into three groups. Coverage of most plant species in group II was low. Species in group II -1 occurred only in site D. Coverages of Sium suave and Scirpus triangulatus in group II-1 were high in site D, Species in Group II-2 occurred in site A and B. Only Zizania latifolia in site A and Artemisia princeps in site B were dominant species. Species in group II-3 occurred in site C only. Typha orientalis was remarkably dominant species. Species in group II except S. suave and T. orientalis occurred only several floors in specific site.

Among the major dominant plant species in group I, we selected species which have over $10 \%$ coverage at a floor (Table 4). A. keisak, L. japonica, P. sieboldii, P. australis, J. effusus, L. lucidus, O. undulatifolius, C. dickinsii, P. ukishiba and P. thunbergii were recorded in all abandoned paddy terraces, but, S. gracilistyla was recorded only in two sites. Particularly, site C of deep water level has dominant submerged plant species and coverage of willows was distinguishable. Overall, Cyperaceae, Gramineae and Salicaceae were recorded relatively high in abandoned paddy terraces.

\section{DISCUSSION}

The study sites represent three regions distributed by the mountain ranges which divide watersheds and cli-

Table 2. Species richness and diversity index.

\begin{tabular}{lrrrrr}
\hline & Site A $(\mathrm{N}=7)$ & Site B $(\mathrm{N}=\mathbf{5})$ & Site C $(\mathbf{N}=\mathbf{7})$ & Site D $(\mathrm{N}=\mathbf{8})$ & Mean \\
\hline Species richness & $14.43 \pm 4.69$ & $23.40 \pm 4.28$ & $20.86 \pm 6.89$ & $32.00 \pm 9.13$ & $22.67 \pm 6.25$ \\
Shannon's diversity index & $1.77 \pm 0.33$ & $1.73 \pm 0.21$ & $1.40 \pm 0.22$ & $1.64 \pm 0.21$ & $1.56 \pm 0.25$ \\
\hline
\end{tabular}


Table 3. Dominant plant species recorded in abandoned paddy terraces.

\begin{tabular}{|c|c|c|c|c|c|}
\hline Group & Abbreviation & Species & Group & Abbreviation & Species \\
\hline \multirow[t]{28}{*}{ I } & A.fr & Amorpha fruticosa & & S.of & Sanguisorba officinalis \\
\hline & A.in & Aeschynomene indica & & S.wi & Scirpus wichurae \\
\hline & A.ke & Aneilema keisak & & T.re & Trifolium repens \\
\hline & O.ja & Oenanthe javanica & & & \\
\hline & A.ts & Agropyron tsukushiense & II-1 & T.an & Typha angustifolia \\
\hline & B.fr & Bidens frondosa & & S.kol & Salix koreensis \\
\hline & C.bi & Carex biwensis & & C.ep & Calamagrostis epigeios \\
\hline & C.co & Commelina communis & & S.tr1 & Scirpus triangulatus \\
\hline & C.dil & Carex dickinsii & & C.si & Carex siderosticta \\
\hline & C.di2 & Carex dimorpholepis & & S.su & Sium suave \\
\hline & E.ku & Eleocharis kuroguwai & $\mathrm{II}-2$ & P.pe & Persicaria perfoliata \\
\hline & I.gl & Isachne globosa & & P.se & Persicaria senticosa \\
\hline & J.ef & Juncus effusus & & R.mu & Rosa multiflora \\
\hline & L.ja & Leersia japonica & & L.pr & Ludwigia prostrata \\
\hline & L.lu & Lycopus lucidus & & S.te & Sanguisorba tenuifolia \\
\hline & I. ja & Isoetes japonica & & M.sa & Miscanthus sacchariflorus \\
\hline & O.un & Oplismenus undulatifolius & & A.pr & Artemisia princeps \\
\hline & P.au & Phragmites australis & & S.sa & Spiraea salicifolia \\
\hline & P.bi & Panicum bisulcatum & & Z.la & Zizania latifolia \\
\hline & P.lo & Pueraria lobata & & P.al & Pennisetum alopecuroides \\
\hline & P.si & Persicaria sieboldii & II-3 & S.ch & Smilax china \\
\hline & P.th & Persicaria thunbergii & & T.or & Typha orientalis \\
\hline & P.uk & Pseudoraphis ukishiba & & H.ve & Hydrilla verticillata \\
\hline & R.ps & Robinia pseudoacacia & & P.di & Potamogeton distincuts. \\
\hline & S.gr & Salix gracilistyla & & E.du & Eleocharis dulcis \\
\hline & S.ko2 & Salix koriyanagi & & P.ja & Phragmites japonica \\
\hline & S.mo & Sphagnum mosses & & S.tr2 & Scirpus triqueter \\
\hline & P.te & Peucedanum terebinthaceum & & A.ju & Albizia julibrissin \\
\hline
\end{tabular}

Table 4. Plant species over $10 \%$ coverage at a site in group I.

\begin{tabular}{lll}
\hline \multicolumn{1}{c}{ Site A } & \multicolumn{1}{c}{ Site B } & Site C and D \\
\hline Aneilema keisak & Aneilema keisak & Aneilema keisak \\
Leersia japonica & Leersia japonica & Leersia japonica \\
Persicaria sieboldii & Persicaria sieboldii & Persicaria sieboldii \\
Phragmites australis & Phragmites australis & Phragmites australis \\
Juncus effuses var. decipiens & Juncus effuses var. decipiens & Juncus effuses var. decipiens \\
Lycopus lucidus & Lycopus lucidus & Lycopus lucidus \\
Oplismenus undulatifolius & Oplismenus undulatifolius & Oplismenus undulatifolius \\
Persicaria thunbergii & Persicaria thunbergii & Persicaria thunbergii \\
Carex dickinsii & Carex dickinsii & \\
Salix gracilistyla & & Salix gracilistyla \\
& Typha orientalis & Typha orientalis
\end{tabular}


mate zones. This indicates that each region might have different environmental condition. CA analysis confirmed that studied sites can be grouped into three, which were originally suggested by the relative location of the sites in South Korea. Such different climate could affect soil formation because a quantity of precipitation or a time and period of raining could be an important factor. Soil condition was a similar gradient among floors in the same abandoned paddy terraces but a quite difference among the locations. These environmental differences among the abandoned paddy terraces were confirmed by Duncan's test. Among differences in environmental factors, $\mathrm{K}^{+}, \mathrm{Ca}^{2+}, \mathrm{Na}^{+}$, and $\mathrm{Mg}^{2+}$ contents were extremely high in site B. Site B was located near the east coast, so it could be affected by salt spray (Barbour and DeJong 1977) and shell crusts which were easily found in soil sample of this site. Water depth was also significantly different among the abandoned paddy terraces, not floors. In general, water level was low (less than $30 \mathrm{~cm}$ ) and consistent through a year in all abandoned paddy terraces. However, site $\mathrm{C}$ showed a high physical gradient and water depth was quite different among the floors. Site $\mathrm{C}$ was disturbed by human activities and local government conserves this area as habitats of Nannophya pygmaea which is an endangered species in Korea. So, local government has managed geomorphology to have diverse water level.

A total of 141 species were investigated in sum of whole abandoned paddy terraces and 98 species were overlapped in all abandoned paddy terraces. 55 species were dominant plant species. CA analysis showed that all dominant species could be assigned to 4 groups. There are 10 common plant species having over $10 \%$ coverage of a floor in all abandoned paddy terraces. This indicates similar distribution pattern of dominant species despite site differences. We can expect 10 species in any between 10 and 15 years old abandoned paddy terraces in South Korea because tree layer was lower than $10 \%$ coverage and shrub layer was lower than $20 \%$ coverage (Lee 2006). Generally, abandoned paddy terraces in mountainous valley about 10 years old would show slow growth rate of vegetation because other abandoned paddy fields could be recovered with sprout placed in there but abandoned paddy terraces might be affected by newly entering seed (Bazzazz 1968, Harrison and Werner 1982, Inouye et al 1987, Lee 1995). The coverage of Salix spp. was high in site A and C. Salix could generally germinate in low water level condition. However, water level of site $\mathrm{C}$ was high. This means that site $\mathrm{C}$ was disturbed by anthropogenic activities for the conservation of this area. The original water level at site $\mathrm{C}$ might be low for willow seed to germi- nate. High water level might make site $\mathrm{C}$ not dominated by $P$. thunbergii that is dominant species in other abandoned paddy fields (Byun et al. 2008). T. orientalis and $S$. suave occurred at all floors at site $\mathrm{C}$ and $\mathrm{D}$, respectively. As S. suave is a common forb inhabiting easily and continuously increasing in wetlands with appropriate nutrients (Green and Galatowitsch 2002). Also, T. orientalis was a dominant species in site $\mathrm{C}$ only. These species could be established by human during management activities for the conservation.

This study confirmed that water depth was the most important factor for early successional stage in abandoned paddy terraces (Weiher and Keddy 1995). Also, diverse water depth induces diverse plant species because high environmental gradient could provide diverse conditions for diverse habitats (Ackerly 2003, Pausas et al. 2003). However, consistent deep water in a lentic wetland could limit the inhabitation of plant species (Miller et al. 2003).

There was the similar early development of plant community even though the abandoned paddy terraces showed different environmental conditions through they were divided into groups according to regions. In general, ecosystem development is affected by environmental conditions. In particular, climate and physico-chemical characteristics could have a strong effect on the development of vegetation structure (Mitsch and Gosselink 2007). However, development of plant community was similar in all abandoned paddy terraces in this study. This result might come from focusing dominant species which are determined by water level.

After abandoned, paddy fields in flat ground depending on irrigation systems might be dried. However, water regime in abandoned paddy terraces were mainly affected by around mountain stream and precipitation for water resource and levee and abandoned paddy terraces maintained nearly always wet condition and water level was maintained at a consistent level because of entire levees around arable fields (Park et al. 2006). Even though monsoonal climate experienced heavy rain during summer season, water depth in abandoned paddy terraces could keep at a constant level by slopes and levees due to flowing excessive quantity of water to downhill. Furthermore, inaccessibility to these locations could be also advantage to the disturbance by anthropogenic activities. For those reasons, abandoned paddy terraces could be showed lownutrient (conductivity of 30 to $40 \mu \mathrm{S} / \mathrm{cm}$ ), which could relatively make interspecific competition weaken (Greulich et al. 2000). Very high nutrient levels were not to be favor of co-occurrence for species with contrasting nutrient re- 
quirements and nutrient level at abandoned paddy terraces were very low (Bornette et al. 1998). This might be accounted by diverse flora and the Red List species were recorded in abandoned paddy terraces (Uematsu et al. 2010). Thus, keeping consistent shallow water level and low nutrients condition were important characteristics to allow abandoned paddy terraces to develop similar level of plant community. It could be explained by the environmental sieve model (van der Valk 1981). Introduced species and survived species could be determined by environmental characteristics. A succession in wetlands began to open water and introduced species could be affected by characteristics of water regime. In particular, water depth was one of important factors to decide a process of early stage of succession (Mitsch and Gosselink 2007). Even though seeds of some species could be distributed over the wetlands by wind, animals or another means, they might be determined whether they could germinate and settle or not by environmental factors as filters that was assembly rules (Keddy 1992) and early settlement effect. After establishment, it seemed that what species would develop to the dominant plant community or not could be affected by another condition which could be competition between plant species or change topography or soil condition depending on plant community.

\section{CONCLUSION}

Early development of plant community in abandoned paddy terraces in South Korea could be determined by water regime rather than climate and physico-chemical characteristics of soil. This came from the similar water regime and location of abandoned paddy terraces, which play an important role in recruiting plant species. We conclude that early development of plant community in abandoned paddy terraces is similar in Korea even though the environmental conditions are different.

\section{ACKNOWLEDGEMENTS}

We thank to Tae Hyeon Kim for helping field work and many experiments in laboratory. This study was supported by the Center for Aquatic Ecosystem Restoration (CAER) of the Eco-STAR project from the Ministry of Environment (MOE), Republic of Korea (EW33-08-12) and Korea Ministry of Environment as "The Eco-Innovation project (416-111-010)" and Brain Korea 21.

\section{Literature Cited}

Ackerly DD. 2003. Community, assembly, niche conservatism, and adaptive evolution in changing environments. Int J Plant Sci 164: 165-184.

Allen SE, Grimshaw HM, Parkinson JA, Quarmby C. 1974. Chemical analysis of Ecological Materials. Blackwell Scienific Publications, Oxford.

Barbour MG, DeJong TM. 1977. Response of west coast beach taxa to salt spray, seawater inundation, and soil salinity. Bull Torrey Bot Club 104: 29-34.

Bazzaz FA. 1968. Succession on abandoned fields in the Shanee Hills southern Illinois. Ecology 49: 924-936.

Bornette G, Amoros C, Lamouroux N. 1998. Aquatic plant diversity in riverine wetlands: the role of connectivity. Freshw Biol 39: 267-283.

Boyle J. 2004. A comparison of two methods for estimating the organic matter content of sediments. J Paleolimnol 31: 125-127.

Bray RH, Kurtz LT. 1945. Determination of total, organic and available forms of phosphorus in soils. Soil Sci 59: 39-45.

Byun CH, Kwon GJ, Lee D, Wojdak JM, Kim JG. 2008. Ecological assessment of plant succession and water quality in abandoned rice fields. J Ecol Field Biol 31: 213-223.

Carter MR. 1993. Soil Sampling and Methods of Analysis. Lewis Publishers, Boca Raton, FL.

Casanova MT, Brock MA. 2000. How do depth, duration and frequency of flooding influence the establishment of wetland plant communities? Plant Ecol 147: 237-250.

Comin FA, Romero JA, Hernandez O, Menendez M. 2001. Restoration of wetlands from abandoned rice fields for nutrient removal, and biological community and landscape diversity. Restor Ecol 9: 201-208.

Fennessy MS, Cronk JK, Mitsh WJ. 1994. Macrophyte productivity and community development in created freshwater wetlands under experimental hydrological conditions. Ecol Eng 3: 469-484.

Foster D, Swanson F, Aber J, Burke I, Brokaw N, Tilman D, Knapp A. 2003. The importance of land-use legacies to ecology and conservation. BioScience 53: 77-88.

Fukamachi K, Oku H, Miyake A. 2005. The relationships between the structure of paddy levees and the plant species diversity in cultural landscapes on the west side of Lake Biwa, Shiga, Japan. Landsc Ecol Eng 1: 191-199.

Green EK, Galatowitsch SM. 2002. Effects of Phalaris arundinace and nitrate- $\mathrm{N}$ addition on the establishment of wetland plant communities. J App Ecol 39: 134-144.

Greulich S, Bornettea G, Amorosa C, Roelofsb JMG. 2000. Investigation on the fundamental niche of a rare species: an experiment on establishment of Luronium natans. 
Aquat Bot 66: 209-224.

Harrison JS, Werner PA. 1982. Colonization by oak seedlings into a heterogeneous successional habitat. Can J Bot 62: 559-563.

Inouye RS, Huntly NJ, Tilman D, Tester JR, Stillwell M, Zinnel KC. 1987. Old-field succession on a Minnesota sand plain. Ecology 68: 12-26.

Kamphake LJ, Hannah SA, Cohen JM. 1967. Automated analysis for nitrate by hydrazine reduction. Water Res 1: 205-216.

Keddy PA. 1992. Assembly and response rules: two goals for predictive community ecology. J Veg Sci 3: 157-164.

Keddy PA. 2000. Wetland Ecology: Principles and Conservation. Cambridge University Press, Cambridge.

Kercher SM, Zedler JB. 2004. Multiple disturbances accelerate invasion of reed canary grass (Phalaris arundinacea L.) in a mesocosm study. Oecologia 138: 455-464.

Kim JG, Park JH, Choi BJ, Sim JH, Kwon GJ, Lee BA, Lee YW, Ju EJ. 2004. Method in Ecology. Bomoondang, Seoul. (in Korean)

Kim TC, Gim US, Kim JS, Kim DS. 2006. The multi-functionality of paddy farming in Korea. Paddy Water Environ 4: 169-179.

Korea Institute of Geoscience and Mineral Resources. 2012. Searching system of geological information. http:// www.kigam.re.kr. Accessed on 1 December 2012.

Lee CS, You YH, Robinson GR. 2002. Secondary succession and natural habitat restoration in abandoned rice fields of Central Korea. Restor Ecol 10: 306-314.

Lee GS. 2006. Changes of species diversity and development of vegetation structure during abandoned field succession after shifting cultivation in Korea. J Ecol Field Biol 29: 227-235.

Lee TB. 2003. Colored Flora of Korea. Hyangmunsa, Seoul. (in Korean)

Matthews JW, Peralta AL, Flanagan DN, Baldwin PM, Soni A, Kent AD, Endress AG. 2009. Relative influence of landscape vs. local factors on plant community assembly in restored wetlands. Ecol App 19: 2108-2123.

Miller RC, Zedler JB. 2003. Response of native and invasive wetland plants to hydroperiod and water depth. Plant Ecol 167: 57-69.

Mitsch WJ, Gosselink JG. 2000. Wetlands, 4th ed. John Wiley \& Sons, Inc., New York, NY.

Murphy J, Riley JP. 1962. A modified single solution method for the determination of phosphate in natural waters. Anal Chim Acta 27: 31-36.

Naiman RJ, Decamps H. 1997. The ecology of interfaces: riparian zones. Ann Rev Ecol Syst 28: 621-658.
Okasanen J, Blanchet FG, Kindt R, Legendre P, Minchin PR, O'Hara RB, Simpson GL, Solymos P, Stevens MHH, Wagner H. 2012. Community Ecology Package. http:// vegan.r-forge.r-project.org. Accessed on 1 December 2012.

Park MY, Yim YR, Kim KG, Joo YW. 2006. The status and characteristics of wetlands created from within abandoned rice paddy fields in South Korea. J Korean Environ Restor Revegetation Technol 9: 1-15. (in Korean)

Pausas JG, Carreras J, Ferre A, Font X. 2003. Coarse-scale plant species richness in relation to environmental heterogeneity. J Veg Sci 14: 661-668.

Rejmankova E. 2011. The role of macrophytes in wetland ecosystems. J Ecol Field Biol 34: 333-345.

Rickelfs RE. 1987. Community diversity: relative roles of local and regional processes. Science 235: 167-171.

Rickey MA, Anderson RC. 2004. Effects of nitrogen addition on the invasive grass Phragmites australis and a native competitor Spartina pectinata. J Appl Ecol 41: 888-896.

Shannon CE, Weaver W. 1949. The Mathematical Theory of Communication. University of Illinois Press, Urbana, IL.

Solorzano L. 1969. Determination of ammonia in natural waters by the phenolhypochlorite method. Limnol Oceanogr 14: 799-801.

Toner M, Keddy P. 1997. River hydrology and riparian wetlands: a predictive model for ecological assembly. Ecol Appl 7: 236-246.

Topp GC. 1993. Soil water content. In: Soil Sampling and Methods of Analysis (Carter MR, ed). Lewis Publishers, Boca Raton, FL. pp 541-557.

Uematsu Y, Koga T, Mitsuhashi H, Ushimaru A. 2010. Abandonment and intensified use of agricultural land decrease habitats of rare herbs in semi-natural grasslands. Agr Ecosyst Environ 135: 304-309.

US Fish and Wildlife Service. 1996, National List of Vascular Plant Species that Occur in Wetlands. http://library.fws. gov/Pubs9/wetlands_plantlist96.pdf. Accessed on 1 December 2012.

van der Valk AG. 1981. Succession in wetlands: a Gleasonian approach. Ecology 62: 688-696.

Weiher E, Keddy PA. 1995. The assembly of experimental wetland plant communities. Oikos 73: 323-335.

Yamada S, Okubo S, Kitagawa Y, Takeuchi K. 2007. Restoration of weed communities in abandoned rice paddy fields in the Tama Hills, Central Japan. Agr Ecosyst Environ 119: 88-102.

Zobel M. 1992. Plant species coexistence-the role of historical, evolutionary and ecological factors. Oikos 65: 314320 . 